\title{
Quality Characteristics and Volatile Profile of Macarons Modified with Walnut Oilcake By-Product
}

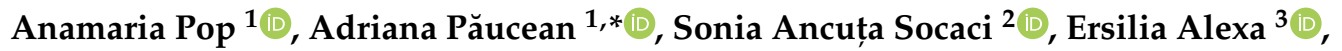 \\ Simona Maria Man ${ }^{1} \mathbb{D}$, Vlad Mureșan ${ }^{1} \mathbb{D}$, Maria Simona Chiş ${ }^{1} \mathbb{D}$, Liana Salanță ${ }^{\mathbb{D}}$, \\ Iuliana Popescu ${ }^{\text {(D) }}$, Adina Berbecea ${ }^{4}$ and Sevastiţa Muste ${ }^{1}$ (D) \\ 1 Department of Food Engineering, Faculty of Food Science and Technology, \\ University of Agricultural Sciences and Veterinary Medicine, 400372 Cluj-Napoca, Romania; \\ anamaria.pop@usamvcluj.ro (A.P.); simona.man@usamvcluj.ro (S.M.M.); vlad.muresan@usamvcluj.ro (V.M.); \\ simona.chis@usamvcluj.ro (M.S.C.); sevastita.muste@usamvcluj.ro (S.M.) \\ 2 Department of Food Science, Faculty of Food Science and Technology, \\ University of Agricultural Sciences and Veterinary Medicine, 400372 Cluj-Napoca, Romania; \\ sonia.socaci@usamvcluj.ro (S.A.S.); liana.salanta@usamvcluj.ro (L.S.) \\ 3 Department of Food Control, Faculty of Agro-Food Technologies, \\ Banat University of Agricultural Sciences and Veterinary Medicine “King Michael I of Romania", 300641 \\ Timişoara, Romania; alexa.ersilia@yahoo.ro \\ 4 Department of Soil Sciences, Faculty of Agriculture, Banat University of Agricultural Sciences and Veterinary \\ Medicine "King Michael I of Romania", 300641 Timişoara, Romania; iuliapopescu2002@yahoo.com (I.P.); \\ adinaberbecea@yahoo.com (A.B.) \\ * Correspondence: adriana.paucean@usamvcluj.ro; Tel.:+40-745-264041
}

Academic Editors: Maria Beatriz Prior Pinto Oliveira and Rita Carneiro Alves Received: 31 March 2020; Accepted: 5 May 2020; Published: 8 May 2020

\begin{abstract}
Walnut oilcake is a low-cost by-product of the edible oil industry but at the same time it is a valuable source of dietary fiber, natural antioxidants, and polyunsaturated fatty acids. In the context of health-friendly confectionary food products and to reduce the production cost, the aim of this study was to investigate the effect of walnut oilcake by-product on the quality characteristics and volatile profile of modified macarons. For this purpose, GC-MS and ITEX/GC-MS techniques were used to obtain the fatty acids methyl esters and the volatile profiles; physicochemical analyzes were performed to determine the nutritional characteristics and a nine-point hedonic scale test was performed for the sensory characteristics. The substitution of almond flour with $0 \%, 10 \%, 25 \%$ and $50 \%$ walnut oilcake powder increased the fiber, total phenolic content, and antioxidant capacity. Hedonic scores of the macaron samples made with different percentage of walnut oilcake decreased to additions of over $10 \%$. Moreover, this result is emphasized by Pearson's correlation parameters indicating as optimal addition for modified macarons, percentages up to $10 \%$ of walnut oilcake. This approach could reduce the costs related to the acquisition of the ingredients due to the oilcake price which is $3 \%$ of the almonds flour price.
\end{abstract}

Keywords: walnut oilcake; by-product utilization; macarons; quality characteristics; volatile profile; sensory evaluation

\section{Introduction}

Macaron, a premium Western dessert, is small, circular shaped, crispy and moist textured cookie [1]. First produced in Italy, it is nowadays a luxury dessert loved all over the world through its association with French desserts [2,3] and it is also considered an expensive dessert [4]. The macaron has always been known as a cookie made only with sweet meringue and ground almond, characterized by a specific 
texture and taste, which increase the complexity of the sensorial perception. The addition of new ingredients can help to reformulate traditional recipes, providing countless creative possibilities [5].

Meringue is a basic baking product used to give light texture and bulk to desserts such as cakes and cookies. The role of meringues is very important for making macaroons as well [6]. When whipping the egg white quickly at a constant speed, the egg white protein forms bubbles. The sugar added to the whipped egg white absorbs moisture and forms a dense and shiny meringue [7].

Nowadays, food manufacturers (e.g., cookie factories and confectioneries) prefer ready-to-use liquid egg products to whole eggs. These products are more favorable because the user does not have to deal with breakage or storage of egg shells potentially infected with feces $[8,9]$.

Food innovation can be considered as a process of combining ingredients using new techniques and/or novel raw materials. Innovations can also be a result of a combination of ingredients from existing recipes [10]. The process of innovation should account for the mastery of complexity where ingredients, texture, and taste merge to create this complexity with the purpose to bring significant and obvious benefit for consumers: it increases the variety of options available with a variation in combinations of ingredients, texture, taste, and product shapes and sizes [5].

Walnut oilcake flour is produced from walnut press-cake, a by-product from the cold pressing of walnut kernels and is considered a new product with potential use in the baking industry as a supplement or even as a replacement for wheat flour in the manufacture of bread, biscuits and cakes [11]. Its other use is to provide a source of natural favoring in these foods [12]. Other aspects to be considered in walnut oilcake valorization are recent changes in peoples' dietary habits and consumers' preference for food products without artificial additives (i.e., preservatives, artificial sweeteners, etc.) [9] The biggest challenge of the scientific world is to provide viable alternative models that combine food production with an efficient valorization strategy of waste and by-product, minimization of energy consumption, and environmental protection [13]. Oilcake from walnuts kernel is a rich source of protein and carbohydrates. Based on its particular technological properties, it is recommended to be used in the manufacture of vegetables, cereal products, sugary and flour-based confection foods [14]. Also, walnut press-cake is a rich source of bioactive compounds. Most of the phenolics in walnut are present in the defatted walnut matter and these antioxidant compounds remain in the walnut press-cake after cold-pressing. In addition, walnut press-cake has a high amount of tocopherol which has an important role in human health [11]. Walnuts are rich in both, linoleic acid and $\alpha$-linolenic acid (ALA), the plant $\mathrm{n}-3$ fatty acids. These compounds are important contributors to the human health due to their beneficial effects such as: protecting against the development of coronary heart disease and sudden cardiac death, lowering blood cholesterol, preservation or enhancement of low density lipoprotein (LDL) resistance to oxidation and improvement of endothelial function [15]. Walnuts are known to be a good source of essential linoleic acid, and therefore of polyunsaturated fatty acids (PUFA), which decreases LDL-cholesterol and increases HDL-cholesterol, moreover, they also contain phytosterols, dietary fiber, phenolics and tocopherols that may be beneficial for health [16-19]. The purpose of this study was to evaluate the influence of walnut oilcake powder (WP), on quality, textural profile, volatile profile and sensory characteristics of modified macarons in order to obtain pastry goods with-out food coloring and with improved quality characteristics. Walnut oilcake is used in most countries as fodder for animals and while the price varies from year to year due to the weather conditions, it remains cheaper than the almond flour, being the walnut oilcake price around $3 \%$ of the almond flour price. Through valorization of the walnut oilcake by-product, the cost with ingredients for produce modified macarons will be significantly reduced. Adding walnut oilcake by-product powder to the macarons will lead to improved quality of modified macarons, while simultaneously reducing costs production. 


\section{Results}

\subsection{The Chemical Composition and Mineral Profile of the Walnut Oilcake Powder}

The approximate composition of the walnut oilcake powder (WP) is summarized in Table 1. The results are similar to those reported previously [12,14,19-21]. The residual oil content from WP is higher than reported values $[14,19,20]$ which ranged between $6 \%$ and $18.2 \%$ and lower than $36.80 \%$ [11]. Similar values (20.3\%) were also found [12]. Protein content in WP is lower than reported by several studies [11,12,14,19-21]. WP has high C18:2 and C18:3 contents and low saturated fatty acid/unsaturated fatty acid (SFAs/UFAs) value (Table 2).

Table 1. Chemical composition and mineral content of walnut oilcake powder.

\begin{tabular}{cc}
\hline Parameters & (WP) \\
\hline Proximate composition, \% f.w. & \\
\hline Moisture content, & $5.95 \pm 0.57$ \\
Protein, & $10.30 \pm 0.28$ \\
Oil, & $21.93 \pm 0.19$ \\
Crude fiber, & $6.79 \pm 0.28$ \\
Ash, & $5.28 \pm 0.13$ \\
Carbohydrates, & $49.75 \pm 0.74$ \\
\hline TPC, mgGAE/100 g dw. & $136.33 \pm 4.04$ \\
DPPH, \% & $53.00 \pm 2.65$ \\
\hline Minerals, mg/100 g f.w. & \\
$\mathrm{K}$ & $506.88 \pm 0.20$ \\
$\mathrm{P}$ & $267.37 \pm 0.47$ \\
$\mathrm{Mg}$ & $128.24 \pm 0.85$ \\
$\mathrm{Ca}$ & $105.30 \pm 1.11$ \\
$\mathrm{Fe}$ & $2.98 \pm 0.18$ \\
$\mathrm{Zn}$ & $2.29 \pm 0.14$ \\
$\mathrm{Mn}$ & $1.77 \pm 0.25$ \\
$\mathrm{Cu}$ & $1.70 \pm 0.21$ \\
$\mathrm{Cd}$ & $0.070 \pm 0.01$ \\
$\mathrm{Cr}$ & $0.034 \pm 0.01$ \\
$\mathrm{Ni}$ & $0.18 \pm 0.04$ \\
\hline
\end{tabular}

All determinations were performed in triplicate; f.w.-fresh weight; d.w.— $d r y$ weight.

These results are aligned with reported data [22]. Walnut oilcake has high TPC and antioxidant capacity (Table 1), most of the phenolics in walnut are present in the defatted walnut matter and these antioxidant compounds remain in the oilcake after cold pressing [11]. The total phenolic content (TPC) was found in WP at the value of $136.33 \mathrm{mgGAE} / 100 \mathrm{~g} \mathrm{~d} . \mathrm{w}$. and radical scavenging activity value DPPH (53\% inhibition). Similar results for by-products reused in the food industry have been obtained [23]; authors have reported that TPC values ranged from $133.93 \mathrm{mgGAE} / 100 \mathrm{~g}$ d.w. to $335.88 \mathrm{mgGAE} / 100 \mathrm{~g}$ d.w., and from $32.74 \%$ to $57.87 \%$ for radical scavenging activity, respectively. Regarding the nutritional value, results have shown that potassium, phosphorus, magnesium, and calcium had the highest levels of concentration for walnuts oilcakes, $506.88 \mathrm{mg} / 100 \mathrm{~g}, 267.37 \mathrm{mg} / 100 \mathrm{~g}$ and $128.24 \mathrm{mg} / 100 \mathrm{~g}$, respectively (Table 1). Generally, the mineral content, according to their amount/100 g of product, was as follows: $\mathrm{K}>\mathrm{P}>\mathrm{Mg}>\mathrm{Ca}>\mathrm{Fe}>\mathrm{Zn}>\mathrm{Mn}>\mathrm{Cu}$. Our results were similar compared to the mineral values reported for Moldavian walnut oilcake [24], using the same method of analysis The sequence of mineral contents in Moldavian walnut oilcake products was $\mathrm{K}>\mathrm{Mg}>\mathrm{Ca}>\mathrm{Fe}>\mathrm{Zn}>\mathrm{Cu}>\mathrm{Na}$, except the $\mathrm{P}, \mathrm{Mn}$ that were not detected, compared to Romanian walnut oilcake. These differences of mineral content may be due to growth conditions, varieties, genetic factors, harvesting time, soil properties, geographical variations and analytical procedures $[25,26]$. 
Table 2. Fatty acids and volatile profile composition of walnut oilcake powder (WP).

\begin{tabular}{|c|c|c|c|}
\hline \multicolumn{3}{|c|}{ Fatty Acids } & \multirow{2}{*}{$\frac{(\mathrm{WP})}{(\%)}$} \\
\hline $\begin{array}{c}\text { Shorthand } \\
\text { Nomenclature }\end{array}$ & Fatty Acid Name & Type & \\
\hline C 6:0 & Caproic & SFA & $0.29 \pm 0.04$ \\
\hline C 8:0 & Caprylic & SFA & $0.60 \pm 0.03$ \\
\hline $10: 0$ & Capric & SFA & $0.11 \pm 0.06$ \\
\hline $12: 0$ & Lauric & SFA & $1.02 \pm 0.12$ \\
\hline $14: 0$ & Myristic & SFA & $0.22 \pm 0.06$ \\
\hline $16: 0$ & Palmitic & SFA & $5.06 \pm 0.32$ \\
\hline $18: 1(n-9)$ & Oleic & MUFA, $\omega-9$ & $30.20 \pm 0.98$ \\
\hline $18: 3(n-3)$ & Linolenic & PUFA $\omega-3$ & $10.64 \pm 0.53$ \\
\hline $18: 2(n-6)$ & Linoleic & PUFA $\omega-3$ & $54.43 \pm 0.49$ \\
\hline$\sum$ SFAs & - & - & $7.30 \pm 0.17$ \\
\hline$\sum$ PUFAs & - & - & $65.07 \pm 0.13$ \\
\hline$\sum$ UFAs & - & - & $95.27 \pm 0.54$ \\
\hline$\sum$ SFAs/ $\sum$ UFAs & - & - & $0.07 \pm 0.04$ \\
\hline$n-6 / n-3$ & - & - & $5.11 \pm 0.42$ \\
\hline Volatile profile & & & $(\mathrm{WP})$ \\
\hline $\begin{array}{l}\text { Volatile } \\
\text { Compounds }\end{array}$ & $\begin{array}{l}\text { RI (Retention } \\
\text { Indices) }\end{array}$ & Characteristic Odour * & $\begin{array}{l}\text { Conc. (\% of Total } \\
\text { Peak Area) }\end{array}$ \\
\hline \multicolumn{4}{|l|}{ Alcohols } \\
\hline Pentan-1-ol & 759 & $\begin{array}{l}\text { Malty, alcoholic } \\
\text { whiskey }\end{array}$ & $0.92 \pm 0.04$ \\
\hline Hexan-1-ol & 851 & $\begin{array}{l}\text { Ethereal, oil, alcohol, } \\
\text { green, fruity, sweet, } \\
\text { woody, floral }\end{array}$ & $0.23 \pm 0.05$ \\
\hline \multicolumn{4}{|l|}{ Aldehyde } \\
\hline Hexanal & 801 & $\begin{array}{l}\text { Fresh, green, fatty, } \\
\text { aldehydic, grass, leafy, } \\
\text { fruity, sweaty }\end{array}$ & $9.69 \pm 0.03$ \\
\hline $\begin{array}{c}\text { Benzaldehyde } \\
\text { Ketone }\end{array}$ & 958 & Almond, burnt sugar & $0.53 \pm 0.12$ \\
\hline $\begin{array}{l}\text { 1-Phenylethanone } \\
\text { Terpenes and } \\
\text { Terpenoids }\end{array}$ & 1042 & Almond, floral & $1.61 \pm 0.09$ \\
\hline$\alpha$-Pinene & 939 & $\begin{array}{l}\text { Fresh, sweet, green, } \\
\text { woody, earthy }\end{array}$ & $0.42 \pm 0.06$ \\
\hline$\beta$-Pinene & 982 & Pine, resin, turpentine & $9.20 \pm 0.77$ \\
\hline$\beta$-Myrcene & 992 & $\begin{array}{l}\text { Tropical, fruity with } \\
\text { mango shades, grassy }\end{array}$ & $1.45 \pm 0.07$ \\
\hline p-Cymene & 1028 & $\begin{array}{l}\text { Citrus, sweet, herbal, } \\
\text { spicy }\end{array}$ & $0.41 \pm 0.05$ \\
\hline $\begin{array}{l}\text { D-Limonene } \\
\text { Acids }\end{array}$ & 1031 & Citrus, mint & $11.02 \pm 0.20$ \\
\hline $\begin{array}{l}\text { Benzoic Acid } \\
\text { Esters }\end{array}$ & 1277 & Balsamic & $0.94 \pm 0.05$ \\
\hline $\begin{array}{l}\text { 2-Methylpropyl } \\
\text { acetate }\end{array}$ & 778 & $\begin{array}{c}\text { Fruity, flowery, banana, } \\
\text { pear }\end{array}$ & $19.93 \pm 0.95$ \\
\hline Pentyl acetate & 916 & Herbal & $0.38 \pm 0.06$ \\
\hline $\begin{array}{c}\text { Methyl } \\
\text { hexanoate }\end{array}$ & 1000 & Fruity, fresh, sweet & $0.28 \pm 0.04$ \\
\hline Ethyl hexanoate & 1001 & Apple, fruity & $11.55 \pm 0.08$ \\
\hline Hexyl acetate & 1012 & Fruity, herbal & $23.73 \pm 0.07$ \\
\hline $\begin{array}{l}\text { Ethyl octanoate } \\
\text { Others }\end{array}$ & 1042 & Orange & $3.87 \pm 0.07$ \\
\hline Nonane & 900 & Alkane & $3.64 \pm 0.10$ \\
\hline N.D. & - & - & $0.18 \pm 0.02$ \\
\hline
\end{tabular}

All determinations were performed in triplicate * drawn from data base mentioned in Section 3.6. 


\subsection{Fatty Acids Methyl Esters Content and Volatile Compounds of Walnut Oilcake Powder}

By means of the ITEX/GC-MS technique, a total of 19 volatile compounds was separated from the walnut oil cake powder on a ZB-5MS capillary column, of which 18, comprising two alcohols, two aldehydes, one ketone, five terpenes, three acids, two esters and other compounds like toluene were identified based on their mass spectra (Table 2).

Among the ketone class in WP, 1-phenylethanone is characterized by a sweet, floral and almond-like aroma $[27,28]$. 1-Phenylethanone was identified in all samples and non-significant differences between the macaron samples were recorded $(p>0.05$, Table 2$)$. Another compound with perceived almond and burnt sugar flavor was benzaldehyde. This would contribute to maintaining an aroma similar to that achieved by classic macarons. Most of the isolated and identified volatile compounds have pleasant aromas (sweet, fruity, herbal) and therefore the addition of WP may not negatively contribute to the final aroma of macarons.

\subsection{The Effect of Walnut Oilcake Addition on Physicochemical Composition and Nutritional Quality of Modified Macarons}

\subsubsection{Chemical Composition for Modified Macarons with Walnut Oilcake and Their Textural} Profile Analyses

The proximate composition of the macarons with walnut oilcake (M0, M10, M25, M50) is summarized in Table 3. Incorporation of the WP in macarons has a significant influence on the major components $(p<0.05)$, except for protein and oil content.

Table 3. Chemical composition for modified macarons with walnut oilcake and their textural profile analyses.

\begin{tabular}{ccccc}
\hline Parameters & M0 (Control) & M10 & M25 & M50 \\
\hline $\begin{array}{c}\text { Proximate composition, } \\
\text { \% f.w. }\end{array}$ & & & & \\
\hline Moisture content & $6.34 \pm 0.50^{\mathrm{a}}$ & $7.16 \pm 0.31^{\mathrm{b}}$ & $8.08 \pm 0.23^{\mathrm{c}}$ & $10.63 \pm 0.42^{\mathrm{d}}$ \\
Protein & $7.13 \pm 0.27^{\mathrm{a}}$ & $7.30 \pm 0.20^{\mathrm{a}}$ & $7.81 \pm 0.26^{\mathrm{a}}$ & $7.61 \pm 0.14^{\mathrm{a}}$ \\
Oil & $8.74 \pm 0.40^{\mathrm{a}}$ & $8.97 \pm 0.13^{\mathrm{a}}$ & $8.85 \pm 0.45^{\mathrm{a}}$ & $9.03 \pm 0.10^{\mathrm{a}}$ \\
Crude fiber & $4.38 \pm 055^{\mathrm{a}}$ & $4.86 \pm 0.21^{\mathrm{ab}}$ & $5.79 \pm 0.32^{\mathrm{c}}$ & $6.79 \pm 0.40^{\mathrm{d}}$ \\
Ash & $1.67 \pm 0.25^{\mathrm{a}}$ & $1.73 \pm 0.33^{\mathrm{a}}$ & $1.88 \pm 0.28^{\mathrm{a}}$ & $1.91 \pm 0.07^{\mathrm{a}}$ \\
Carbohydrates & $72.88 \pm 0.35^{\mathrm{d}}$ & $69.98 \pm 1.15^{\mathrm{c}}$ & $68.06 \pm 0.66^{\mathrm{b}}$ & $64.03 \pm 0.28^{\mathrm{a}}$ \\
Energy, kcal/100 g & $350.44^{\mathrm{d}}$ & $342.71^{\mathrm{c}}$ & $336.10^{\mathrm{b}}$ & $322.73^{\mathrm{a}}$ \\
TPC, mgGAE/100 g d.w. & $20.33 \pm 2.40^{\mathrm{a}}$ & $35.66 \pm 4.93^{\mathrm{b}}$ & $42.33 \pm 3.06^{\mathrm{c}}$ & $62.66 \pm 4.03^{\mathrm{d}}$ \\
DPPH, \% & $31.04 \pm 2.62^{\mathrm{a}}$ & $35.06 \pm 3.52^{\mathrm{b}}$ & $38.10 \pm 1.51^{\mathrm{c}}$ & $49.97 \pm 2.53^{\mathrm{d}}$ \\
\hline Texture parameters & & & & \\
Hardness, g & $276 \pm 55^{\mathrm{d}}$ & $261 \pm 15^{\mathrm{c}}$ & $248 \pm 38^{\mathrm{b}}$ & $56 \pm 12^{\mathrm{a}}$ \\
Total work, $\mathbf{m J}$ & $4.57 \pm 1^{\mathrm{b}}$ & $4.5 \pm 1.3^{\mathrm{b}}$ & $4.5 \pm 1.2^{\mathrm{b}}$ & $1.6 \pm 0.6^{\mathrm{a}}$ \\
\hline
\end{tabular}

Values expressed are means \pm standard deviation; $\mathrm{M} 0=0 \%$ walnut oilcake powder supplemented almond powder (control sample); M10 = 10\% walnut oilcake powder supplemented almond powder; M25 = 25\% walnut oilcake powder supplemented almond powder; $\mathrm{M} 50=50 \%$ walnut oilcake powder supplemented almond powder; f.w.-fresh weight; d.w.--dry weight; a-d Mean values in the same column with different superscript letters differ significantly $(p<0.05)$.

The increase in moisture content from $6.34 \%$ for the control sample to $10.63 \%$ for $50 \%$ WP sample can be explained by the increasing of the fiber content which leads to higher water absorption during meringue preparation. Contrariwise, total carbohydrates amount decreased (from $72.88 \%$ to $63.35 \%$ ) as the content of WP in the samples increased.

The protein, ash content, and oil content recorded non-significant differences for all the macaron samples $(p>0.05)$, as showed in Table 3. A cheaper raw material source like walnut oilcake by-product does not significantly change the values of these nutritional parameters. 
Taking into account that in recent years cellulose has been considered to be one of the major ingredients to develop products of functional purpose, oilcakes with increased content of cellulose could be introduced as a new ingredient rich in insoluble dietary fibers [14].

The energy content of food is essential in dealing with problems associated with normal nutrition, under nutrition and obesity [29]. The energy value of the macaron samples decreased significantly $(p<0.05)$ from 350.44 to $322.73 \mathrm{kcal}$, directly proportional to the addition of walnut oilcake. Sample W0 contained the highest value while sample W50 had the least. Consumption of low energy density foods is fundamental to many weight loss plans [29,30].

Regarding the total phenolic content (TPC) in samples with different substitution level of WP, ranged from $20.33 \mathrm{mg} \mathrm{GAE} / 100 \mathrm{~g}$. d.w. (M0) to $62.66 \mathrm{mg} \mathrm{GAE} / 100 \mathrm{~g}$. d.w. (M50) and the antioxidant capacity (DPPH) ranged from 31.04\% (M0) to 49.97\% (M50). This trend of increased TPC and antioxidant capacity values for the pastry products with addition of walnut oilcake have been recorded in other similar studies $[14,31]$. The TPC and antioxidant capacity of the macaron samples were increased significantly $(p<0.05)$ by substituting the almond powder with walnut oilcake. A strong positive linear correlation was found between walnut oilcake percentage and TPC $(r=0.984)$, walnut oilcake percentage and inhibition of DPPH radical $(r=0.988)$. The improved antioxidant properties of the macarons with walnut oilcake might be due to the phenolic content of walnut oilcake. The total phenolic content is greatly influenced by factors, such as temperature, precipitation, natural causes (infection, damage, and pests), fruit maturity stage, and storage [32].

The macaron's texture is an important attribute for consumers. The textural parameters of the macaron are given in Table 3. The control sample recorded the highest value of hardness $(276 \pm 55 \mathrm{~g})$, followed by M10 (261 $\pm 15 \mathrm{~g}), \mathrm{M} 25(248 \pm 38 \mathrm{~g})$, and M50 (56 $\pm 12 \mathrm{~g})$. As the amount of the walnut oilcake powder increased in the macaron composition, the hardness decreased significantly $(p<0.05)$. The decrease in hardness, probably resulted from lower fat content of walnut oilcake compared to the fat content of the almond flour [11]. The drastic decline of the hardness at 50\% WP addition lead to the conclusion that addition of walnut oilcake in macarons formulation must be under this value. The work necessary to overcome the internal strength of bonds within the macarons, together with the work performed by the sample against the compressing force as it is being removed, were measured as total work. The values recorded for total work [mJ], as shown in Table 3, followed the same trend of decreasing values $(p<0.05)$, indicating that the addition of WP influenced drastically the internal strength of the bonds within the macarons samples-decreasing from $4.57 \mathrm{~mJ}$ (control sample M0) to 1.6 mJ (sample M50-50\% WP).

\subsubsection{Mineral Content of Macarons with Walnut Oilcake}

The mineral composition of macaron samples (M0, M10, M25, M50) is shown in Table 4. Micronutrients as minerals are also important components when considering the nutritional characteristic of a potential food ingredient [33]. The mineral content of macarons is provided by the almond flour and WP added in different percentages in their composition. The scientific literature states that walnuts and almonds are very rich sources of minerals [34-37]. Almonds are one of the most nutrient-rich forms of food available [31] having a high content in minerals, as follows: calcium (264 mg/100 g), magnesium (268 mg/100 g), phosphorus (484 mg/100 g), potassium (705 mg/100 g), zinc $(3.08 \mathrm{mg} / 100 \mathrm{~g})$, copper $(1.00 \mathrm{mg} / 100 \mathrm{~g})$ and manganese $(2.28 \mathrm{mg} / 100 \mathrm{~g})$. The high mineral content of the walnut oilcake powder and almonds powder $(\mathrm{K}, \mathrm{P}, \mathrm{Mg}, \mathrm{Ca}, \mathrm{Fe}, \mathrm{Zn})$ is reflected, as we expected, in the mineral content of macaron samples. Significant differences $(p<0.05)$ of mineral content were recorded between macaron samples with different content of WP (Table 4). Potassium, phosphorus, magnesium, and calcium quantity decreased in the macaron samples, with the addition of WP in percentage of $10 \%, 25 \%$ and $50 \%$ WP compared to the control ( $0 \% \mathrm{WP})$. 
Table 4. Mineral content of modified macaron with walnut oilcake.

\begin{tabular}{|c|c|c|c|c|c|c|c|c|c|c|c|}
\hline Samples & $\mathbf{K}$ & $\mathbf{P}$ & $\mathrm{Mg}$ & $\mathrm{Ca}$ & $\mathrm{Fe}$ & $\mathrm{Zn}$ & Mn & $\mathrm{Cu}$ & $\mathrm{Cd}$ & $\mathrm{Cr}$ & $\mathrm{Ni}$ \\
\hline \multicolumn{12}{|c|}{ mg/100 g f.w. } \\
\hline $\begin{array}{c}\text { M0 } \\
\text { (Control) }\end{array}$ & $\begin{array}{c}577.49 \\
\pm 0.53^{\mathrm{d}}\end{array}$ & $\begin{array}{c}363.19 \\
\pm 0.16^{d}\end{array}$ & $\begin{array}{c}206.24 \\
\pm 0.80^{\mathrm{d}}\end{array}$ & $\begin{array}{c}201.74 \\
\pm 0.45^{\mathrm{d}}\end{array}$ & $\begin{array}{l}2.79 \pm \\
0.59^{\mathrm{a}}\end{array}$ & $\begin{array}{l}2.07 \pm \\
0.04^{\mathrm{a}}\end{array}$ & $\begin{array}{l}1.71 \pm \\
0.51^{\mathrm{a}}\end{array}$ & $\begin{array}{l}0.73 \pm \\
0.12^{\mathrm{a}}\end{array}$ & $\begin{array}{c}0.083 \pm \\
0.01^{\mathrm{a}}\end{array}$ & $\begin{array}{c}0.039 \pm \\
0.02^{\mathrm{a}}\end{array}$ & $\begin{array}{l}0.19 \pm \\
0.03^{a}\end{array}$ \\
\hline M10 & $\begin{array}{c}575.32 \\
\pm 0.11^{\mathrm{c}}\end{array}$ & $\begin{array}{c}361.75 \\
\pm 0.45^{\mathrm{c}}\end{array}$ & $\begin{array}{c}202.17 \\
\pm 0.26^{\mathrm{c}}\end{array}$ & $\begin{array}{c}197.12 \\
\pm 0.23^{c}\end{array}$ & $\begin{array}{l}2.87 \pm \\
0.35^{b}\end{array}$ & $\begin{array}{l}2.35 \pm \\
0.38^{b}\end{array}$ & $\begin{array}{l}1.85 \pm \\
0.31 \mathrm{~b}\end{array}$ & $\begin{array}{l}0.78 \pm \\
0.21^{\mathrm{a}}\end{array}$ & $\begin{array}{c}0.077 \pm \\
0.03^{\mathrm{a}}\end{array}$ & $\begin{array}{c}0.037 \pm \\
0.03^{\mathrm{a}}\end{array}$ & $\begin{array}{l}0.17 \pm \\
0.04^{\mathrm{a}}\end{array}$ \\
\hline M25 & $\begin{array}{r}573.26 \\
\pm 0.19^{b}\end{array}$ & $\begin{array}{c}359.12 \\
\pm 0.44^{b}\end{array}$ & $\begin{array}{c}197.03 \\
\pm 0.40^{b}\end{array}$ & $\begin{array}{c}190.08 \\
\pm 0.93^{b}\end{array}$ & $\begin{array}{l}3.01 \pm \\
0.32^{c}\end{array}$ & $\begin{array}{l}2.78 \pm \\
0.13^{c}\end{array}$ & $\begin{array}{l}1.99 \pm \\
0.43^{c}\end{array}$ & $\begin{array}{l}0.85 \pm \\
0.18^{\mathrm{ab}}\end{array}$ & $\begin{array}{c}0.067 \pm \\
0.03^{\mathrm{a}}\end{array}$ & $\begin{array}{c}0.036 \pm \\
0.02^{\mathrm{a}}\end{array}$ & $\begin{array}{l}0.16 \pm \\
0.04^{\mathrm{a}}\end{array}$ \\
\hline M50 & $\begin{array}{c}540.67 \\
\pm 0.35^{\mathrm{a}}\end{array}$ & $\begin{array}{c}356.73 \\
\pm 0.80^{\mathrm{a}}\end{array}$ & $\begin{array}{c}191.82 \\
\pm 0.48^{\mathrm{a}}\end{array}$ & $\begin{array}{c}179.07 \\
\pm 0.27^{\mathrm{a}}\end{array}$ & $\begin{array}{l}3.25 \pm \\
0.42 \mathrm{~d}\end{array}$ & $\begin{array}{l}3.05 \pm \\
0.66^{d}\end{array}$ & $\begin{array}{l}2.27 \pm \\
0.38^{b}\end{array}$ & $\begin{array}{l}0.96 \pm \\
0.31^{b}\end{array}$ & $\begin{array}{c}0.063 \pm \\
0.03^{\mathrm{a}}\end{array}$ & $\begin{array}{c}0.033 \pm \\
0.01^{\mathrm{a}}\end{array}$ & $\begin{array}{l}0.15 \pm \\
0.04^{\mathrm{a}}\end{array}$ \\
\hline
\end{tabular}

Values expressed are means \pm standard deviation; $\mathrm{M} 0=0 \%$ walnut oilcake powder supplemented almond powder (control sample); M10 = 10\% walnut oilcake powder supplemented almond powder; M25 = 25\% walnut oilcake powder supplemented almond powder; M50 = 50\% walnut oilcake powder supplemented almond powder; f.w.-fresh weight; a-d Mean values in the same column with different superscript letters differ significantly $(p<0.05)$.

Pearson minerals' correlation for elements like Fe, $\mathrm{Cu}, \mathrm{Mn}$, and $\mathrm{Zn}(1.00,1.00,0.998$ and 0.971, respectively) showed strong positive relationship between the percentage of walnut powder addition in the final baked products. On the other side, negative strong Pearsons' correlations were found for elements like $\mathrm{P}, \mathrm{Mg}, \mathrm{Ca}, \mathrm{Cd}$ and $\mathrm{Cr}(-0.990,-0.988,-1.00,-0.951$ and 0.989 , respectively), showing that walnut powder addition decreased the final baked content on these minerals. The quantity of essential elements as $\mathrm{Fe}, \mathrm{Mn}, \mathrm{Zn}$ and $\mathrm{Cu}$, allows the walnuts oil cake, as well as the almond flour, to be considered as an excellent source of bio-elements [35-39].

\subsection{The Effect of Walnut Oilcake Addition on Fatty Acids Methyl Esters Content of Modified Macarons}

In the macaron samples, a total of nine fatty acid methyl esters (FAMEs) were identified, out of which six were classified as being saturated (SFAs), one as MUFA, and two as PUFAs. The main compounds from the saturated group in WP were palmitic acid, reaching around of $5.06 \%$ of total fatty acids, followed by lauric acid and caprylic acid. Walnut oilcake powder has high C18:2 and C18:3 contents and low ratio of saturated/unsaturated fatty acid (SFA/UFA). These results are aligned with the reported data [11,22].

Among PUFAs, linoleic acid reached the highest value; it could be noticed that linoleic acid content increased significantly with the WP addition in macarons. According to the study by [40], MUFA have been demonstrated to improve pancreatic beta-cell function and regulation of postprandial glycemia and insulin sensitivity. PUFA may act on the central nervous system protecting neuronal and cell-signaling function and maintenance, useful adjuvants to prevent, delay or ameliorate a number of chronic diseases in older people. As it can be seen in Table 5, the proportion of linoleic acid, linolenic acid, total unsaturated fatty acid (UFA) and total polyunsaturated fatty acids (PUFA) of the macarons samples increased with the increased percentage of walnut oilcake powder (WP), at the same time the proportion of the palmitic acid in fatty acid composition decreased. The increment in the proportion of oleic acid was significant $(p<0.05)$. 
Table 5. Fatty acids methyl esters content (\% of total fatty acids methyl esters) of macaron samples.

\begin{tabular}{|c|c|c|c|c|c|c|}
\hline $\begin{array}{l}\text { Shorthand } \\
\text { Nomenclature }\end{array}$ & $\begin{array}{c}\text { Fatty } \\
\text { Acid } \\
\text { Name }\end{array}$ & Type & $\begin{array}{c}\text { M0 } \\
\text { (Control) }\end{array}$ & M10 & M25 & M50 \\
\hline $6: 0$ & Caproic & SFA & $0.12 \pm 0.04^{a}$ & $0.14 \pm 0.04^{\mathrm{a}}$ & $0.23 \pm 0.05^{a b}$ & $0.31 \pm 0.06^{b}$ \\
\hline $8: 0$ & Caprylic & SFA & $0.03 \pm 0.03^{a}$ & $0.18 \pm 0.03^{b}$ & $0.21 \pm 0.08^{a b}$ & $0.28 \pm 0.08^{b}$ \\
\hline 10:0 & Capric & SFA & $0.04 \pm 0.03^{\mathrm{a}}$ & $0.08 \pm 0.05^{\mathrm{a}}$ & $0.16 \pm 0.06^{\mathrm{a}}$ & $0.18 \pm 0.05^{a}$ \\
\hline $12: 0$ & Lauric & SFA & $0.12 \pm 0.06^{\mathrm{a}}$ & $0.62 \pm 0.11^{b}$ & $0.14 \pm 0.06^{\mathrm{a}}$ & $0.04 \pm 0.03^{a}$ \\
\hline $14: 0$ & Myristic & SFA & $0.18 \pm 0.05^{\mathrm{a}}$ & $0.61 \pm 0.15^{d}$ & $0.46 \pm 0.07^{c}$ & $0.31 \pm 0.06^{b}$ \\
\hline $16: 0$ & Palmitic & SFA & $11.96 \pm 0.65^{c}$ & $11.83 \pm 0.20^{c}$ & $11.50 \pm 0.50^{b}$ & $9.24 \pm 0.21^{\mathrm{a}}$ \\
\hline $18: 1(n-9)$ & Oleic & MUFA, $\omega-9$ & $43.29 \pm 0.73^{a}$ & $52.47 \pm 0.50^{b}$ & $56.77 \pm 0.35^{c}$ & $58.11 \pm 0.65^{d}$ \\
\hline $18: 3(n-3)$ & Linolenic & PUFA $\omega-3$ & $2.53 \pm 0.17^{a}$ & $3.06 \pm 0.11^{b}$ & $3.35 \pm 0.38^{b}$ & $4.51 \pm 0.18^{c}$ \\
\hline $18: 2(n-6)$ & Linoleic & PUFA, $\omega-6$ & $25.35 \pm 0.44^{\mathrm{a}}$ & $25.75 \pm 0.59^{a}$ & $28.46 \pm 0.49^{b}$ & $36.29 \pm 0.44^{c}$ \\
\hline$\sum$ SFAs & - & - & $12.45 \pm 0.49^{b}$ & $13.46 \pm 0.37^{c}$ & $12.70 \pm 0.55^{b}$ & $10.36 \pm 0.30^{a}$ \\
\hline$\sum$ PUFAs & - & - & $27.88 \pm 0.62^{a}$ & $28.81 \pm 0.23^{b}$ & $31.81 \pm 0.21^{\mathrm{c}}$ & $40.08 \pm 0.38^{d}$ \\
\hline$\sum$ UFAs & - & - & $71.17 \pm 0.16^{\mathrm{a}}$ & $81.28 \pm 0.73^{b}$ & $87.58 \pm 0.26^{c}$ & $98.19 \pm 0.62^{d}$ \\
\hline$\sum$ SFAs/ $\sum$ UFAs & - & - & $0.17 \pm 0.04^{\mathrm{a}}$ & $0.16 \pm 0.04^{\mathrm{a}}$ & $0.14 \pm 0.05^{\mathrm{a}}$ & $0.10 \pm 0.03^{a}$ \\
\hline$n-6 / n-3$ & - & - & $10.80 \pm 0.28^{c}$ & $8.41 \pm 0.37^{b}$ & $8.49 \pm 0.15^{b}$ & $8.04 \pm 0.61^{a}$ \\
\hline
\end{tabular}

Note: Values expressed are means \pm standard deviation of three replicates; $\mathrm{WP}=$ Walnut oilcake powder; $\mathrm{M} 0=0 \%$ walnut oilcake powder supplemented almond powder (control); M10 $=10 \%$ walnut oilcake powder supplemented almond powder; M25 $=25 \%$ walnut oilcake powder supplemented almond powder; M50 $=50 \%$ walnut oilcake powder supplemented almond powder; FA—-fatty acid; SFA — saturated fatty acids; PUFA—-polyunsaturated fatty acids; MUFA — monounsaturated fatty acids; SFA/UFA — saturated/unsaturated fatty acid; UFA — unsaturated fatty acid; $\sum$ UFA $=$ MUFA $+\sum$ PUFA. a-d Mean values in the same column with different superscript letters differ significantly $(p<0.05)$, according to Duncan's multiple range test.

In the present study of modified macarons, a decrease of the omega-6/omega-3 ratio can be observed; the decrement is directly proportional to the percentage of WP added in macaron samples ranging from $10.8(\mathrm{M} 0)$ to 8.04 (M25). This result is due to the significant increment $(p<0.05)$ of omega-3 acids content from 2.53 in control sample to 4.51 in M25. The result is important in the conclusion's light of different studies which clearly show an increase in the risk of obesity and cardiovascular diseases as the amount of omega- 6 fatty acids and the omega-6/omega-3 ratio increase [41].

Macarons with $25 \%$ walnut press-cake powder had the highest linoleic acid $(36.29 \%)$, linolenic acid $(4.51 \%)$, and total UFA $(98.19 \%)$ and the lowest SFAs/UFAs value (0.10). The results are in agreement with those obtained previously [11].

\subsection{The Effect of Walnut Oilcake Addition on Volatile Compounds Content of Modified Macarons}

Using the ITEX/GC-MS technique, in the present study of modified macarons samples, a total number of 24 volatile compounds were separated on the capillary column, out of which 23 were identified by their mass spectra. Of the identified compounds three were alcohols, two aldehydes, two ketones, twelve terpenes, one acid, two esters, all listed in Table 6, along with their characteristic odors $[23,28,42,43]$. 
Table 6. Volatile compounds content of the modified macarons with walnut oilcake.

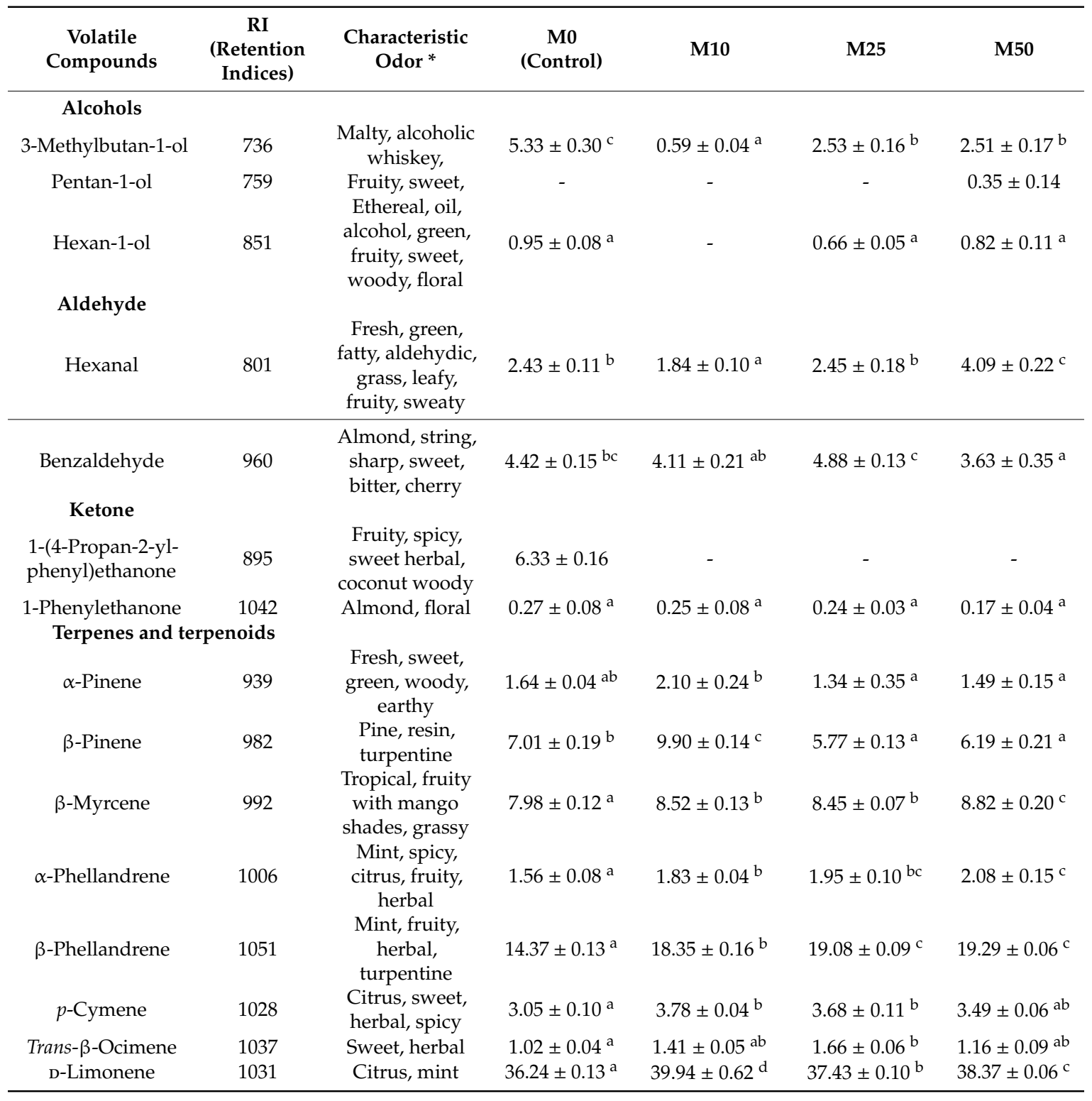


Table 6. Cont.

\begin{tabular}{|c|c|c|c|c|c|c|}
\hline $\begin{array}{c}\text { Volatile } \\
\text { Compounds }\end{array}$ & $\begin{array}{c}\text { RI } \\
\text { (Retention } \\
\text { Indices) }\end{array}$ & $\begin{array}{l}\text { Characteristic } \\
\text { Odor * }\end{array}$ & $\begin{array}{c}\text { M0 } \\
\text { (Control) }\end{array}$ & M10 & M25 & M50 \\
\hline$\beta$-Terpinene & 1074 & $\begin{array}{l}\text { Citrus, tropical, } \\
\text { fruity, oily, } \\
\text { woody }\end{array}$ & $1.63 \pm 0.05^{a b}$ & $2.16 \pm 0.08^{b}$ & $1.44 \pm 0.08^{\mathrm{a}}$ & $1.52 \pm 0.10^{\mathrm{a}}$ \\
\hline$\gamma$-Terpinene & 1074 & $\begin{array}{l}\text { Citrus, tropical, } \\
\text { fruity, oily, } \\
\text { woody }\end{array}$ & $1.53 \pm 0.05^{\mathrm{a}}$ & $1.73 \pm 0.10^{a}$ & $3.02 \pm 0.13^{b}$ & $1.63 \pm 0.12^{\mathrm{a}}$ \\
\hline $\begin{array}{l}\text { 1,3,8-p-Mentha- } \\
\text { triene }\end{array}$ & 1110 & $\begin{array}{c}\text { Woody, citrus, } \\
\text { grassy }\end{array}$ & - & $0.60 \pm 0.08^{a}$ & $1.21 \pm 0.08^{b}$ & $0.75 \pm 0.11^{\mathrm{ab}}$ \\
\hline $\begin{array}{l}\text { 1-Methyl-4-(1-methyl- } \\
\text { ethenyl)benzene, } \\
\text { Acids }\end{array}$ & 1284 & $\begin{array}{l}\text { Spicy, balsamic, } \\
\text { nutty, terpenic }\end{array}$ & $0.88 \pm 0.04^{\mathrm{ab}}$ & $0.43 \pm 0.08^{a}$ & $1.28 \pm 0.10^{b}$ & $0.79 \pm 0.09 \mathrm{ab}$ \\
\hline $\begin{array}{l}\text { Benzoic acid } \\
\text { Esters }\end{array}$ & 1277 & Balsamic & $1.27 \pm 0.09^{a}$ & $0.91 \pm 0.07^{\mathrm{a}}$ & $2.10 \pm 0.10^{b}$ & $0.70 \pm 0.03^{a}$ \\
\hline Ethyl hexanoate & 1001 & $\begin{array}{l}\text { Fruity, sweet, } \\
\text { apple }\end{array}$ & $0.53 \pm 0.04$ & - & - & - \\
\hline Hexyl acetate & 1011 & $\begin{array}{l}\text { Fruity, spicy, } \\
\text { herbal, citrus, } \\
\text { green }\end{array}$ & $1.14 \pm 0.08^{b}$ & $0.54 \pm 0.11^{\mathrm{a}}$ & $0.73 \pm 0.05^{\mathrm{a}}$ & $1.15 \pm 0.08^{b}$ \\
\hline \multicolumn{7}{|l|}{ Others } \\
\hline Toluene & 775 & Solvent & $0.42 \pm 0.07^{\mathrm{a}}$ & $0.33 \pm 0.10^{\mathrm{a}}$ & $0.43 \pm 0.06^{\mathrm{a}}$ & $0.30 \pm 0.02^{\mathrm{a}}$ \\
\hline N.D. & - & - & - & $0.67 \pm 0.05^{\mathrm{a}}$ & $1.07 \pm 0.08^{b}$ & $0.75 \pm 0.09^{\mathrm{a}}$ \\
\hline
\end{tabular}

Note: ${ }^{a-f}$ different superscripts in a row indicate significant difference within samples $(p<0.05)$. All determinations were performed in triplicate N.D.-not detected; * drawn from data base mentioned in Section 3.6.

According to [44] hexanal was the largest compound in different varieties walnut kernels, followed by 1-pentanol, pentanal, 1-hexanol and then 1-penten-3-ol and are important contributors to walnut aroma. In the present study a high amount of hexanal was identify in the sample with the largest quantity of WP addition (M50), with a significant difference $(p<0.05)$ comparing to control, being characterized by having an aldehydic, grassy, leafy, fruity, sweety flavor. According to [19] the profile of the studied volatile walnut oils consists of aldehydes (31-37\%), acids (20-38\%) and alcohols (16-36\%) with different proportions depending on the cultivar and hexanal-related to green descriptor-is the major contributor within the aldehydes family.

From the ketone group, 1-(4-propan-2-ylphenyl) ethenone was the main volatile compound identified in the control sample, while 1-phenylethanone identified in all samples, recorded nonsignificant value between the macaron samples $(p>0.05)$, being characterized by having an almond, floral flavor. The quantity of these compounds decreased with the addition of WP.

$\alpha$ and $\beta$-pinene are important compounds used in food preservation, due to their antimicrobial activity. More than that, $\alpha$-pinene has been reported to have antitumor activity on a concentration of $8 \mathrm{mg} / \mathrm{L}$ [45]. $\alpha$ and $\beta$-pinene were found in all samples, in a similar level.

Limonene is one of the most common terpenes in nature, having a pleasant citrus-like flavor. The studies evaluating its safety showed that it has a low toxicity, being also biologically active. Limonene has been reported having chemo-preventive activity against different types of cancer such as breast or colorectal ones at a concentration between 0.5 to $12 \mathrm{~g} / \mathrm{m}^{2} /$ day $[28,46]$. The amount of limonene could be correlated with the quality of walnut. Limonene, a typical terpene, was identified as main compound in walnut oil sample from cold press, according to Bail at al. [47]. In our samples, limonene was identified in both control sample and modified macarons samples as being the major volatile compound. The concentration of limonene increased when WP was added to macarons.

\subsection{Pearson's Correlation}

A Pearson's correlation was run to study influence of the walnut oilcake percentage addition on the fatty acids and volatile compounds concentrations in macarons. 
Linolenic, caproic, $\sum$ PUFAs, $\sum$ UFAs and linoleic n-6 recorded positive Pearson's values $(\mathrm{r}=0.990$, $r=0.989, r=0.981$, and $r=0.980$, respectively), showing that the addition of walnut powder strongly influence the amount of these compounds in the final baked goods. On the other side, the $\sum$ SFAs/ $\sum$ UFAs recorded a strong negative Pearson correlation (-0.999), showing that the addition of walnut powder decreased the $\sum$ SFAs/ $\sum$ UFA's value. In contrast, from the volatile compounds only 1-phenylethanone recorded a strong negative Pearson correlation $(r=-0.974)$, indicating that the addition of WP does not significantly influence the aroma profile of macarons and therefore, from this point of view, it can also be used to replace almond flour. Regarding the effect of walnut powder addition on the sensory analysis of macarons, texture and overall acceptability were highly negative influenced, showing Pearson's values such as $r=-0.971$ and $r=-0.971$, respectively.

\subsection{The Effect of Walnut Oilcake Addition on Sensory Analysis of Modified Macarons}

Table 7 shows the scores for the hedonic test of macarons made by addition of walnut oilcake in different percentages. Scores for appearance (color), flavor, taste, texture, and overall acceptance were highest for M10 sample, but not-significant differences compared to the control sample $(p>0.05)$ were found. The highest score for flavor was achieved by sample M25 (8.53) but the result was not significant $(p<0.05)$ compared to the control sample M0 and the sample M10.

Table 7. Sensory evaluation of modified macaron samples.

\begin{tabular}{|c|c|c|c|c|c|}
\hline $\begin{array}{l}\text { Macaron } \\
\text { Samples }\end{array}$ & Appearance & Flavor & Taste & Texture & $\begin{array}{c}\text { Overall } \\
\text { Acceptability }\end{array}$ \\
\hline M0 (Control) & $8.40 \pm 0.42^{b c}$ & $8.18 \pm 0.20^{b}$ & $8.05 \pm 0.35^{c}$ & $8,63 \pm 0.39^{c}$ & $8.30 \pm 0.57^{c}$ \\
\hline M25 & $8.10 \pm 0.71^{b}$ & $8.53 \pm 0.39^{b}$ & $7.23 \pm 0.11^{b}$ & $7.65 \pm 0.21^{b}$ & $7.65 \pm 0.64^{b}$ \\
\hline M50 & $7.20 \pm 0.14^{a}$ & $6.38 \pm 0.31^{a}$ & $6.90 \pm 1.14^{a}$ & $6.03 \pm 0.53^{a}$ & $6.70 \pm 0.28^{a}$ \\
\hline
\end{tabular}

Values expressed are means \pm standard deviation; $\mathrm{M} 0=0 \%$ walnut oilcake powder supplemented almond powder (Control); M10 $=10 \%$ walnut oilcake powder supplemented almond powder; M25 $=25 \%$ walnut oilcake powder supplemented almond powder; M50 = 50\% walnut oilcake powder supplemented almond powder; a-d Mean values in the same column with different superscript letters differ significantly $(p<0.05)$.

This could be explained as a result of the presence of aroma volatile compounds such as $\alpha$-pinene (perceived like fresh, sweet, green, woody and earthy flavor), $\beta$-pinene (perceived like pine and resin flavor), $p$-cymene (perceived like citrus, sweet, herbal and spicy flavor), limonene (perceived like citrus and mint flavor) and 1-methyl-4-(1-methylethenyl) benzene (perceived like spicy, balsamic and nutty, flavor). The perceived flavor may have a positive effect on flavor acceptability of macarons made with up to $25 \%$ addition of walnut oilcake powder. Meanwhile, macaron containing 50\% WP, showed the lowest scores for flavor, taste, texture and overall acceptance $(p<0.05)$. This might be due to the excessive amounts of volatiles and phenolic compounds that can negatively alter the taste of the pastry food products. Similar results were reported previously on pastry products [11,48]. These results pointed out that a partial replacement of almond powder with up to $25 \%$ walnut oilcake in modified macaron increased the flavor of the product. These data suggest that addition of 10\% WP is the optimal concentration for making modified macaron, for all sensory characteristics according to consumer preferences.

\section{Materials and Methods}

\subsection{Supply of Raw Materials and Storage Conditions}

Almond powder (50.6\% fat, from which $3.9 \%$ was saturated fatty acids, $19.7 \%$ total carbohydrates from which $4.8 \%$ was sugars, $11.8 \%$ fiber, $21.3 \%$ protein), sugar powder, egg white, soybean protein isolate and granulated sugar were purchased from local specialized stores (DECO ITALIA SRL, Cluj-Napoca, România). According to the producers, all the ingredients meet the highest quality 
standards. The walnut residual cake, known under the brand name "LUNA SOLAI" was supplied by the TAF PRESOIL SRL company (Cluj, Romania), an important cold pressed oil processor from the Transylvania area [49]. Fresh walnuts, consisting of a range of different cultivars, were harvested from local orchards in July, 2017, and stored in their shells in open mesh bags at $15^{\circ} \mathrm{C}$ until October 2017. The walnut oilcake by-product comes from the oil extraction processing of walnut kernels using a screw cold press (Komet Screw Oil, Expeller CA59G-of $6 \mathrm{~mm}$ of diameter and a screw speed of $30 \mathrm{rpm}$ (IBG Monforts Oekotec GmbH \& Co. KG, Mönchengladbach, Germany), and storage at $15{ }^{\circ} \mathrm{C}$ in sealing plastic containers for one week and then used in experiments. All reagents were of analytical grade. Analytical reagents and chemicals were purchased from Sigma Aldrich (St. Louis, MO, USA).

\subsection{Walnut Oilcake Powder Preparation}

The walnut oilcake by-product were passed through a mill feeder processed by grinding to fine flour $(<300 \mu \mathrm{m}$ ) on a Grindomix (Model GM200, Haan, Germany) laboratory mill at 10,000 rot/min for $50 \mathrm{~s}$, passed through a $0.8 \mathrm{~mm}$ sieve and then homogenized by mixing. Walnut oilcake powder (WP) was used to substitute almond powder (AP) at different amounts $(0-50 \%)$ as it could be seen in Table 8 .

Table 8. Formulation used for the preparation of modified macarons.

\begin{tabular}{cccccc}
\hline \multirow{2}{*}{ Mixing Ratio } & Components (g) & $\begin{array}{c}\text { M0 } \\
\text { (Control) }\end{array}$ & M10 & M25 & M50 \\
\hline \multirow{2}{*}{ Tant pour tant } & Almond powder (AP) & 300 & 270 & 225 & 150 \\
(TPT) & Walnut oilcake powder (WP) & - & 30 & 75 & 150 \\
& Sugar powder & 300 & 300 & 300 & 300 \\
& Egg white-1 & 110 & 110 & 110 & 110 \\
Meringue & Sugar & 300 & 300 & 300 & 300 \\
& Water & 75 & 75 & 75 & 75 \\
& Egg white-2 & 115 & 115 & 115 & 115 \\
& Soybean protein isolate & 10.2 & 10.2 & 10.2 & 10.2 \\
& Citric acid & 3.4 & 3.4 & 3.4 & 3.4 \\
\hline
\end{tabular}

\subsection{Modified Macarons Making Process}

The formulation and the addition percentages of walnut oilcake powder were determined through preliminary industrial experiments and by using information from similar studies [3,50]. The modified macarons were prepared with the addition of oilcake powder at a weight percentage of $0 \%(\mathrm{M} 0), 10 \%$ (M10), 25\% (M25) and 50\% (M50) to the substitution of almond powder. The control sample (M0) was prepared with almond powder $100 \%$. Before the macaron was prepared, the amount of Tant Pour Tant (TPT) was weighed, and the almond powder, walnut oilcake powder and sugar powder were dropped three times in a 30 mesh sieve, and the egg white- 1 were mixed to make dough until the composition becomes the consistency of a paste. On the other hand, meringue was mixed with egg white-2, soybean protein isolate and citric acid, in a medium stage planetary mixer (Precise Heat Mixing Bowl, KitchenAid ${ }^{\circledR}$, Greenville, OH, USA) for 2 min. The sugar and the water were boiled at a temperature of $117^{\circ} \mathrm{C}$ and then the syrup was slowly poured into the mixed egg white to make a meringue by rotating quickly for $13 \mathrm{~min}$, until the temperature drops to $40-42{ }^{\circ} \mathrm{C}$. The finished dough is put in a pastry bag decorating tip couplers and squeezed in a dough tray with a constant weight and left at room temperature for $30 \mathrm{~min}$ to allow a crust to form. The macaroon batter was baked in an oven (Zanolli, Verona, Italy) preheated to $140{ }^{\circ} \mathrm{C}$ for $13 \mathrm{~min}$ with ventilation cooled in a refrigerator for $1 \mathrm{~h}$ and used in experiments. For the textural, moisture, volatile and sensorial profile, analyses were carried out on fresh macarons (on the day of baking) and for the rest of analyses the samples were kept in the freezer temperature. 


\subsection{Proximate Composition Analysis of the Walnut Oilcake Powder and Modified Macarons}

The chemical analysis were carried out according to AACC Approved Methods [51]. Like moisture (44-15.02), lipids (30-25.01), ash (08-01.01), crude fibre (32-07.01) and protein were measured using the Kjeldahl method (46-11.02), nitrogen to protein conversion factor was 5.7. Total carbohydrate (\%) content was calculated as the difference: $100-$ (moisture + ash + proteins + lipids + crude fibres) equation reported in a previous work [21] and also reported by [28]. Energy value was estimated (kcal/100 g) by multiplying the percentage crude protein, crude lipid and carbohydrate by the recommended factor (2.44, 8.37 and 3.57 respectively) as described by Makinde and Adeyemi [29].

\subsubsection{Analysis of Macro and Microelements by Atomic Absorption Spectrophotometry}

The analysis of macro and microelements was carried out according to SR EN 14082: 2003. Briefly, $3 \mathrm{~g}$ sample of mixed macarons were burned for $10 \mathrm{~h}$ at $650{ }^{\circ} \mathrm{C}$ in furnace (Nabertherm B150, Lilienthal, Germany). The ash was dissolved in $\mathrm{HCl} \mathrm{20 \%} \mathrm{and} \mathrm{was} \mathrm{transferred} \mathrm{by} \mathrm{a} \mathrm{final} \mathrm{volume} \mathrm{of} 20 \mathrm{~mL}$ in a volumetric flask. The macroelements ( $\mathrm{K}, \mathrm{Ca}, \mathrm{Mg})$ and microelements (Fe, $\mathrm{Cu}, \mathrm{Zn}$ and $\mathrm{Mn}$ ) were determined by atomic absorption spectroscopy (AAS; 220 FAA equipment, Varian, Mulgrave, Victoria, Australia). Mix standard solutions (ICP Multi Element Standard solution IV CertiPUR) were purchased from Merck, Bucharest, Romania All chemicals and solvents used in this study were of analytical grade. The detection limits (MDL) for analyzed elements were $0.02 \mathrm{ppm}$ for $\mathrm{Mg}$ and $\mathrm{K}, 0.06 \mathrm{ppm}$ for $\mathrm{Fe}, \mathrm{Cu}$, $\mathrm{Zn}, \mathrm{Mn}$, and Ca $0.03 \mathrm{ppm}$. The results were expressed as related to the macarons fresh weight.

\subsubsection{Total Phenolic Content (TPC) and Antioxidant Capacity}

The methods described [11], Refs [52-54] were used with some modification, for total phenols and antioxidant capacity determination. Shortly, a 1-gram sample of mixed macarons was extracted three times with $100 \mathrm{~mL}$ acidified methanol $(85: 15 \mathrm{v} / v, \mathrm{MeOH}: \mathrm{HCl})$ by maceration under continuous stirring (Velp magnetic stirrer, Usmate, Italy) for $24 \mathrm{~h}$. The filtrates were combined in a total extract, which was dried by using a vacuum rotary evaporator (KG_-Laborota 4010 digital rotary evaporator, Heidolph Instruments $\mathrm{GmbH} \& \mathrm{Co}$., Schwabach, Germany) at $40{ }^{\circ} \mathrm{C}$. The dry residues were redissolved in $10 \mathrm{~mL}$ methanol (99.9\% purity) and filtered through a $0.45 \mu$ m nylon filter (Millipore by Merck).

Total phenolic content (TPC) in phenolic extracts was determined by the Folin-Ciocalteu method. $100 \mu \mathrm{L}$ of each extract was shaken for 1 min with $500 \mu \mathrm{L}$ of Folin-Ciocalteu reagent and $6 \mathrm{~mL}$ of distilled water. After the mixture was shaken, $2 \mathrm{~mL}$ of $15 \% \mathrm{Na}_{2} \mathrm{CO}_{3}$ was added and the mixture was shaken once again for $0.5 \mathrm{~min}$. and water was added to reach a final volume of $10 \mathrm{~mL}$. Samples were kept in the dark for $2 \mathrm{~h}$, and then, absorbance was read at $720 \mathrm{~nm}$ on a Shimadzu $1700 \mathrm{UV} /$ visible spectrophotometer (Shimadzu Scientific Instruments, Kyoto, Japan). The total phenol content was read by plotting the gallic acid calibration curve (from 1 to $1500 \mu \mathrm{g} / \mathrm{mL}$ ) and expressed as milligrams of gallic acid equivalents (GAE) per gram of dry weight. The equation or the gallic acid calibration curve was $\mathrm{y}=1.02295 \mathrm{x}+0.08740 ; \mathrm{R}^{2}=0.99614$.

Free radical-scavenging effects of phenolic extracts were measured according to [54,55]. Phenolic extracts of macaron samples were diluted with methanol at 0.5:99.5 ratio. Diluted phenolic extract $(0.1 \mathrm{~mL})$ was added to $3.9 \mathrm{~mL}$ of DPPH solution $(0.025 \mathrm{~g} / \mathrm{L}$ in methanol). The mixture was left for $30 \mathrm{~min}$ in the dark at room temperature. The absorbances of the sample at $515 \mathrm{~nm}$ were measured by a Shimadzu 1700 spectrophotometer against methanol as blank. Negative control was prepared using $0.1 \mathrm{~mL}$ methanol and $3.90 \mathrm{~mL}$ of DPPH. The inhibitory percentage of DPPH (2,2-diphenyl-1picrylhydrazyl) was calculated according to the following equation:

$$
\% \text { Inhibition }=[(\mathrm{Ac}-\mathrm{As}) / \mathrm{Ac}] \times 100
$$

where Ac is the absorbance of the control (absorbance of DPPH solution), and As is the absorbance of the sample. 


\subsection{Determination of Fatty Acid Composition}

\subsubsection{Total Lipid Determination}

Lipids were extracted in petroleum ether using a Soxtest Raypa SX-6 MP (Barcelona, Spain) apparatus. Three $\mathrm{g}$ of crushed macaroons samples were introduced in cartridges and $50 \mathrm{~mL}$ petroleum ether was used for each sample extraction. Parameters were set as follows: temperature: $75^{\circ} \mathrm{C}$, time of extraction: $50 \mathrm{~min}$. Samples were dried to constant weight. Total fat was expressed as percentage from the sample $(\% w / w)$.

\subsubsection{Fatty Acids Profile by GC-MS Analysis}

Fatty acid methyl esters (FAMEs) from total lipids were analyzed using a Shimadzu GCMS-QP2010 PLUS apparatus and an AT-WAX column (30 m, $0.32 \mathrm{~mm}$ i.d., $1 \mu \mathrm{m}$ thickness), (Shimadzu) belonging to the Interdisciplinary Research Platform of Banat University of Agricultural Sciences and Veterinary Medicine King Michael I of Romania. The solvent used for FAMEs was hexane, while the carrier gas (helium) was used at a flow rate of $1.00 \mathrm{~mL} / \mathrm{min}$ and a linear velocity of $37.8 \mathrm{~cm} / \mathrm{s}$. Derivatization was performed for $1 \mathrm{~h}$ at $80{ }^{\circ} \mathrm{C}$ in an ultrasonic bath. An aliquot of $0.1 \mathrm{~g}$ sample was treated with $3 \mathrm{~mL}$ boron trifluoride methanol solution $20 \%(w / v)$. After cooling, $2.5 \mathrm{~mL} \mathrm{NaCl}$ solution $10 \%(w / v)$ was added and methyl esters were extracted in $2 \mathrm{~mL}$ hexane, the organic layer being separated by centrifugation at $1006 \mathrm{G}$ for 15 min using centrifuge Z36 HK (Hermle Labortechnik GmbH, Wehinge, Germany) The hexane solution $(1 \mu \mathrm{L})$ was injected in apparatus. Samples were analyzed keeping the column initially at $140{ }^{\circ} \mathrm{C}$ for $10 \mathrm{~min}$ and then increasing the temperature with $7{ }^{\circ} \mathrm{C} / \mathrm{min}$ up to $250{ }^{\circ} \mathrm{C}$ and maintaining at this temperature for $10 \mathrm{~min}$ (total run: $35.71 \mathrm{~min}$ ). Split ratio was 1:10 and injection port temperature was set at $250{ }^{\circ} \mathrm{C}$. The ion source and interface temperatures were $210{ }^{\circ} \mathrm{C}$ and $255^{\circ} \mathrm{C}$, respectively. FAME peaks were identified using NIST05 library and quantified by area normalization method. Some compounds were unidentifiable due to the lack of authentic samples and library spectra of the corresponding molecules. The percentage of various fatty acids was determined by reporting the peak area corresponding to a specific compound to the total peak area (for all identified constituents) of chromatograms [56].

\subsection{Extraction and Analysis of Volatile Compounds by ITEX/GS-MS}

The extraction of volatile compounds was performed using in-tube extraction (ITEX) technique coupled with their separation and identification by gas-chromatography hyphenated with mass spectrometry (GC-MS) [42]. Briefly, the extraction of volatile compounds was carried out by incubating at $60{ }^{\circ} \mathrm{C}$ for $20 \mathrm{~min}$ and under continuous agitation, a headspace vial containing $1 \mathrm{~g}$ of sample. After incubation the needle of the headspace syringe was introduced into the headspace of the vial and using the syringe plunger, the volatile compounds were adsorbed repeatedly (30 strokes) into a porous polymer fiber microtrap (ITEX-2TRAPTXTA, Tenax TA 80/100 mesh, ea). All the above operations as well the thermal desorption of the volatiles into the GC-MS injector were perform automatically by means of a CombiPAL AOC-5000 autosampler (CTC Analytics, Zwingen, Switzerland). The separation and identification of volatile compounds was carried out on a GC-MS QP-2010 (Shimadzu) model gas-chromatograph-mass spectrometer, using the method described by [47] with some modifications. The separation of volatile compounds was performed on a Zebron ZB-5 ms capillary column of $30 \mathrm{~m} \times 0.25 \mathrm{~mm}$ i.d and $0.25 \mathrm{~mm}$ film thickness. The carrier gas was helium, $1 \mathrm{~mL} / \mathrm{min}$ and the split ratio 1:20. The injector temperature, as well as those of ion source and interface were set at $250^{\circ} \mathrm{C}$. The temperature program of the column oven was: $38^{\circ} \mathrm{C}$ (held for $5 \mathrm{~min}$ ) increased to $110{ }^{\circ} \mathrm{C}$ at $4{ }^{\circ} \mathrm{C} / \mathrm{min}$ and then to $250^{\circ} \mathrm{C}$ at $20^{\circ} \mathrm{C} / \mathrm{min}$ (held for $5 \mathrm{~min}$ ). The MS detection was performed on a quadrupole mass spectrometer operating in full scan (40-400 m/z) electron impact (EI) at ionization energy of $70 \mathrm{eV}$. The volatile constituents of the samples were identified based on their mass spectra, by comparison with those of reference compounds from NIST27 and NIST147 mass spectra libraries and verified with retention indices drawn from [57] or [58]. All peaks found in at least 
two of the three total ion chromatograms (TIC) were taken into account when calculating the total area of peaks $(100 \%)$ and the relative areas of the volatile compounds [28,59].

\subsection{Texture Profile Analysis for Macaron Samples}

The texture of modified macarons with walnut oilcake powder (WP) was tested using a texture analyzer (CT 3 Texture Analyzer (Brookfield Engineering Labs, Middleboro, MA, USA) equipped with $10 \mathrm{~kg}$ load cell. Half macaron (crown or foot of the product) samples (cylindrical shape, $45 \mathrm{~mm}$ diameter and $12 \mathrm{~mm}$ height) were analyzed at room temperature. Texture profile analysis (TPA) was performed for each sample while using the TA41 cylindrical probe, $40 \%$ target deformation, $1 \mathrm{~mm} \mathrm{~s}^{-1}$ test and post-test speed, $5 \mathrm{~g}$ trigger load, and $5 \mathrm{~s}$ recovery time. However, due to the characteristic texture, none of the samples showed structure in the second cycle. Hardness and total work were computed by Texture Pro CT V1.6 software (Brookfield Engineering Labs).

\subsection{Sensory Evaluation}

The sensory analysis of the modified macaron sample was carried out by 50 semi-trained panelists (students and staff of Faculty of Food Science and Technology from Cluj-Napoca), 30\% male and 70\% female, age range: 20-55 years. Panelists were trained prior to evaluation to be familiar with quality attributes of macaron samples. Ethical approval was obtained from the scientific department before the study was conducted. The macarons were served one by one in a disposable plastic container $(10 \mathrm{~cm}$ in diameter), marked with random three-digit number on the containing the sample so that there was no bias against the sample. The sensory test panel evaluated one sample so that the characteristic of each sample did not affect each other, and after rinsing the mouth with water, the next sample was evaluated, according to the method described by [3] with slight modifications, according to [28]. Each panelist analyzed three macaroons from each sample, taking into account the appearance, flavor, taste, texture and overall quality on a nine-point Hedonic scale, in the following sequence: 1-4 represent negative sensations, 5 was neither like nor dislike, and 6-9, which represent positive sensations, 9 meaning extremely like. The consumer preference is directly proportional to the score obtained (in the preference evaluation, the higher the preference, the higher the score).

\subsection{Statistical Analysis}

All experiments are performed in triplicate $(n=3)$. As indicated in the macaron making section, the effect of four percentage of walnut oilcake $(0,10,25$, and $50 \%)$ were analyzed. The obtained data were expressed as means \pm standard deviations. Data were compared using Duncan multiple comparison test by using SPSS version 19 software $(p \leq 0.005)$ (IBM Corp., Armonk, NY, USA).

Pearson correlation was computed on Minitab 19.1 (Minitab Inc., State College, PA, USA) at 95 confidence level, in order to better analyze the influence of WP percentage addition on the macarons' quality characteristics.

\section{Conclusions}

To the best of our knowledge, there are very few works reporting on the relationship between the walnut oilcake addition in baked goods and their fatty acids, volatile and sensory profiles. Walnut oilcake is a low-cost by-product of the oil industry and is a good source of valuable nutrients. The results of this study reveal the effect of walnut oilcake addition on physico-chemical parameters, fatty acids, and volatile profile of macarons with walnut oilcake. Pearson minerals' correlation for $\mathrm{Fe}, \mathrm{Cu}, \mathrm{Mn}$, and $\mathrm{Zn}$ showed strong positive relationship between the percentages of walnut oilcake added in the macarons. Also, linolenic, caproic, $\sum$ PUFAs, $\sum$ UFAs and linoleic n-6 recorded positive Pearson's values, showing that the addition of walnut oilcake strongly influences the amount of these compounds in macarons. From the volatile compounds only 1-phenylethanone recorded a strong negative Pearson correlation, indicating that the addition of walnut oilcake does not significantly influence the aroma profile of macarons. Hedonic scores of the macaron samples made with different 
percentage of walnut oilcake decreased to additions of over $10 \%$. Moreover, this result is emphasized by Pearson's correlation parameters indicating as optimal addition for modified macarons, percentages up to $10 \%$ of walnut oilcake.

Author Contributions: Conceptualization, A.P. (Anamaria Pop), A.P. (Adriana Păucean), and A.B.; methodology, S.A.S., S.M.M., E.A., L.S. and I.P.; software, M.S.C.; validation, S.A.S., and E.A. formal analysis, V.M., S.M.M. and S.A.S.; writing — original draft preparation, A.P. (Anamaria Pop) and A.P. (Adriana Păucean); writing-review and editing, A.P. (Adriana Păucean) supervision, S.M. project administration, A.P. (Anamaria Pop); funding acquisition, A.P. (Anamaria Pop). All authors have read and agreed to the published version of the manuscript.

Funding: This research was funded by Executive Unit for Financing Higher Education, Research, Development, and Innovation (UEFISCDI) within the framework of PN-III-P2-2.1-CI-2017-0743, grant No: 136/CI/2017 and the publication was supported by funds from the National Research Development Projects to finance excellence (PFE)-37/2018-2020 granted by the Romanian Ministry of Research and Innovation.

Acknowledgments: The authors acknowledge the technical support provided by the company TAF PRESOIL SRL known under the brand name "LUNA SOLAI" (Cluj, Romania) by supplied the walnut oilcake by-product and the SC MOTILOR SRL company, known under the brand name "PRALINA" (Cluj, Romania), the beneficiary of this study, respectively the beneficiary of the project mentioned above. The authors acknowledge the technical support provided by the researcher Dan Cristian Vodnar.

Conflicts of Interest: The authors have no conflict of interest regarding the content of this paper.

\section{References}

1. Kim, M.J. Mom's French Cookie Good Macaron; Chung Publisher: Seoul, Korea, 2013; pp. 11-68.

2. Kim, J.I. Physicochemical Properties of Macaroon Prepared with Eclipta Alba. Master's Thesis, Hansung University, Gwangju, Korea, 2015.

3. Kim, M.; Sim, K.H. Quality Characteristics and Antioxidative Activities of Macaron with the Addition of Egg White Powder. Korean J. Food Nutr. 2017, 30, 269-281. [CrossRef]

4. Lee, M.W.; Choi, S.Y.; Yoo, K.M.; Lim, S.Y.; Jung, W.S.; Hwang, I.K. Development of value-added macaroonè with Perilla frutescens powders and their physiological characteristics. Korean J. Food Nutr. 2015, 28, 66-72. [CrossRef]

5. Palczak, J.; Giboreauc, A.; Rogeaux, M.; Delarue, J. How do pastry and culinary chefs design sensory complexity? Int. J. Gastron. Food Sci. 2020, 19, 100182. [CrossRef]

6. Kim, K.H.; Kim, Y.S.; Hong, M.S.; Yook, H.S. Quality characteristics of meringue cookies added with tomato powder. J. Korean Soc. Food Sci. Nutr. 2016, 45, 366-371. [CrossRef]

7. Jeong, S.I. Meringue, powerful combination of sugar and egg white powder. Bakery 2006, 3, 139-140.

8. Yadav, N.K.; Vadehra, D.V. Mechanism of egg white resistance to bacterial growth. J. Food Sci. 1977, 42, 97-99. [CrossRef]

9. Radványi, D.; Juhász, R.; Németh, C.; Suhajda, Á.; Balla, C.; Barta, J. Evaluation of the Stability of Whipped Egg White. Czech J. Food Sci. 2012, 30, 412-420. [CrossRef]

10. Messeni, P.A.; Savino, T. Search, recombination, and innovation: Lessons from haute cuisine. Long. Range Plan. 2014, 47, 224-238. [CrossRef]

11. Bakkalbasi, E.; Raciye Meral, R.; Dogan, I.S. Bioactive compounds, physical and sensory properties of cake made with walnut press-cake. J. Food Qual. 2015, 38, 422-430. [CrossRef]

12. Vanhanen, L.P.; Savage, G.P. The use of peroxide value as a measure of quality for walnut flour stored at five different temperatures using three different types of packaging. Food Chem. 2006, 99, 64-69. [CrossRef]

13. Fărcaş, A.C.; Socaci, S.A.; Diaconeasa, Z.M. Introductory Chapter: From Waste to New Resources. In Food Preservation and Waste Exploitation; IntechOpen: London, UK, 2019; pp. 1-11. [CrossRef]

14. Bochkarev, M.S.; Egorova, E.Y.; Reznichenkoc, I.Y.; Poznyakovskiy, V.M. Reasons for the ways of using oilcakes in food industry. Foods Raw Mater. 2016, 4, 4-12. [CrossRef]

15. Ros, E.; Mataix, J. Fatty acid composition of nuts-Implication for cardiovascular health. Br. J. Nutr. 2006, 96, S29-S35. [CrossRef] [PubMed]

16. Davis, P.; Valacchi, G.; Pagnin, E.; Shao, Q.; Gross, H.B.; Calo, L.; Yokoyamaz, W. Walnuts reduce aortic ET-1 mRNA levels in hamsters fed a high-fat, atherogenic diet. J. Nutr. 2006, 136, 428-432. [CrossRef]

17. Anderson, K.J.; Teuber, S.S.; Gobeille, A.; Cremin, P.; Waterhouse, A.L.; Steinberg, F.M. Walnut polyphenolics inhibit in vitro human plasma and LDL oxidation. J. Nutr. 2001, 131, 2837-2842. [CrossRef] [PubMed] 
18. Amaral, J.S.; Alves, M.; Seabra, R.; Oliveira, B. Vitamin E composition of walnuts (Juglans regia L.): A 3-year comparative study of ifferent cultivars. J. Agric. Food Chem. 2005, 53, 5467-5472. [CrossRef] [PubMed]

19. Ojeda-Amador, R.M.; Salvador, M.D.; Gómez-Alonso, S.; Fregapane, G. Characterization of virgin walnut oils and their residual cakes produced from different varieties. Food Res. Int. 2018, 108, 396-404. [CrossRef]

20. Tarek-Tilistyáka, J.; Juhász-Román, M.; Jekőa, J.; Máthé, E. Short-term storability of oil seeds and walnut cake-microbiological aspect. Acta Aliment. 2014, 43, 632-639. [CrossRef]

21. Montrimaitè, K.; Moščenkova, E. Possibilities of usage of oilcakes from non-traditional oil plants for development of health-friendly functional food products. Food Sci. Appl. Biotech. 2018, 1, 154-164. [CrossRef]

22. Martínez, M.L.; Penci, M.C.; Ixtaina, V.; Ribotta, P.D.; Maestri, D. Effect of natural and synthetic antioxidants on the oxidative stability of walnut oil under different storage conditions. LWT Food Sci. Technol 2013, 51, 44-50.

23. Farcas, A.C.; Mudura, E.; Socaci, S.A.; Dulf, F.V.; Tofana, M. Volatile profile, fatty acids composition and total phenolics content of brewers' spent grain by-product with potential use in the development of new functional foods. J. Cereal Sci. 2015, 64, 34-42. [CrossRef]

24. Grosu, C. Mineral Ccomposition of Walnut Kernel and Walnut Oil Cake; Academia de Studii Economice a Moldovei: Iasi, Romania, 2017; pp. 225-226. Available online: https:/ibn.idsi.md/sites/default/files/imag_ file/225-226.pdf (accessed on 31 January 2020).

25. Özcan, M.M.; İman, C.; Arslan, D. Physico-chemical properties, fatty acid and mineral content of some walnuts (Juglans regia L.) types. Agric. Sci. 2010, 1, 62-67. [CrossRef]

26. Çağlarırmak, N. Biochemical and physical properties of some walnut genotypes (Juglans regia L.). Nahrung. Food 2003, 47, 28-32. [CrossRef] [PubMed]

27. Rajiv, J.; Lobo, S.; Jyothi Lakshmi, A.; Venkateswara Rao, G. Influence of Green Gram Flour (Phaseolus aureus) on the Rheology, Microstructure and Quality of Cookies. J. Texture Stud. 2012, 43, 350-360. [CrossRef]

28. Chis, M.S.; Pop, A.; Păucean, A.; Socaci, S.A.; Ersilia Alexa, E.; Man, S.M.; Monica Bota, M.; Muste, M. Fatty Acids, Volatile and Sensory Profile of Multigrain Biscuits Enriched with Spent Malt Rootles. Molecules 2020, 25, 442. [CrossRef] [PubMed]

29. Makinde, F.M.; Adeyemi, A.T. Quality characteristics of biscuits produced from composite flours of wheat, corn, almond and coconut. Annu. Food Sci. Technol. 2018, 19, 216-225.

30. Rolls, B.J.; Drewnowski, A.; Ledikwe, J.H. Changing the Energy Density of the Diet as a Strategy for Weight Management. J. Am. Diet. Assoc. 2005, 105, 98-103. [CrossRef] [PubMed]

31. Blomhoff, R.; Carlsen, M.H.; Andersen, L.F.; David, R.; Jacobs Jr, D.R. Health benefits of nuts: Potential role of antioxidants. Br. J. Nutr. 2006, 96, 52-60. [CrossRef]

32. Slatnar, A.; Mikulic-Petkovsek, M.; Stampar, F.; Veberic, R.; Solar, A. Identification and quantification of phenolic compounds in kernels, oil and bagasse pellets of common walnut (Juglans regia L.). Food Res. Int. 2015, 67, 255-263. [CrossRef]

33. Fărcaș, A.C.; Socaci, S.A.; Tofană, M.; Mureşan, C.; Mudura, E.; Salanţă, L.; Scrob, S. Nutritional Properties and Volatile Profile of Brewer's Spent Grain Supplemented Bread. Rom. Biotech. Let. 2014, 19, 9705-9714.

34. Lavedrine, F.; Ravel, A.; Villet, A.; Ducros, V.; Alary, J. Mineral composition of two walnut cultivars originating in France and California. Food Chem. 2000, 68, 347-351. [CrossRef]

35. Cosmulescu, S.; Baciu, A.; Achim, G.; Botu, M.; Trandafir, I. Mineral Composition of Fruits in Different Walnut (Juglans regia L.) Cultivars. Not. Bot. Hort. Agrobot. Cluj 2009, 37, 156-160. [CrossRef]

36. Moodley, R.; Kindness, A.; Jonnalagadda, S.B. Elemental composition and chemical characteristics of five edible nuts (almond, Brazil, pecan, macadamia, and walnut) consumed in Southern Africa. J. Env. Sci. Health Part B 2007, 42, 585-591. [CrossRef] [PubMed]

37. Ros, E. Health Benefits of Nut Consumption. Nutrients 2010, 2, 652-682. [CrossRef]

38. Richardson, D.P.; Astrup, A.; Cocaul, A.; Ellis, P. The nutritional and health benefits of almonds: A healthy food choice. Food Sci. Tech. Bul. Funct. Foods 2009, 6, 41-50. [CrossRef]

39. Rodushkin, I.; Engström, E.; Sörlin, D.; Baxter, D. Levels of inorganic constituents in raw nuts and seeds on the Swedish market. Sci. Total Environ. 2008, 392, 290-304. [CrossRef] [PubMed]

40. Grosso, G.; Estruch, R. Nut consumption and age-related disease. Maturitas 2016, 84, 11-16. [CrossRef] [PubMed]

41. Simopoulos, A.P. An Increase in the Omega-6/Omega-3 Fatty Acid Ratio Increases the Risk for Obesity. Nutrients 2016, 8, 128. [CrossRef] 
42. Socaci, S.A.; Socaciu, C.; Mureşan, C.; Fărcaş, A.; Tofană, M.; Vicaş, S.; Pintea, A. Chemometric discrimination of different tomato cultivars based on their volatile fingerprint in relation to lycopene and total phenolics content. Phytochem. Anal. 2014, 25, 161-169. [CrossRef]

43. Li, J.; Dong, M.; Liu, Y.L.; Zhang, L.; Zhang, Y.; Ren, J.N.; Pan, S.Y.; Fan, G. Effect of Food Emulsifiers on Aroma Release. Molecules 2016, 21, 511. [CrossRef]

44. Elmore, J.S.; Nisyrios, I.; Mottram, D.S. Analysis of the headspace aroma compounds of walnuts (Juglans regia L.). Flavour Fragr. J. 2005, 20, 501-506. [CrossRef]

45. Pessôa, M.G.; Pastore, G.M.; Molina, G. Biotransformation of $\alpha$ - and $\beta$-pinene into flavor compounds. Appl. Microbiol. Biotechnol. 2017, 101, 1805-1817.

46. Sun, J.D. Limonene: Safety and Clinical Applications. Altern. Med. Rev. 2007, 12, 259-264. [PubMed]

47. Bail, S.; Stuebiger, G.; Unterweger, H.; Buchbauer, G.; Krist, S. Characterization of volatile compounds and triacylglycerol profiles of nut oils using SPME-GC-MS and MALDI-TOF-MS. Eur. J. Lipid Sci. Technol. 2009, 111, 170-182. [CrossRef]

48. Park, S.H.; Lim, H.S.; Hwang, S.Y. Evaluation of antioxidant, rheological, physical and sensorial properties of wheat flour dough and cake containing turmeric powder. Food Sci. Technol. Int. 2012, 18, 435-443. [CrossRef] [PubMed]

49. Luna Solai. Available online: https://www.lunasolai.com/ (accessed on 31 January 2020).

50. Choi, S.Y.; Lim, S.Y.; Jung, W.S.; Yoo, K.M.; Hwang, I.K. Studies on Quality Characteristics and Biological Activities of Macaroons supplemented with GABA ( $\gamma$-Aminobutyric Acid) Rice Powder and Xylose. J. East. Asian Soc. Diet. Life 2015, 25, 822-829. [CrossRef]

51. AACC. Approved Methods of the American Association of Cereal Chemists, 11th ed.; Methods 38-12; American Association of Cereal Chemists: St. Paul, MN, USA, 2000.

52. Li, L.; Tsao, R.; Yang, R.; Liu, C.; Zhu, H.; Young, J.C. Polyphenolic profiles and antioxidant activities of heratnut (Juglans ailanthifolia var. Cordiformis) and persian walnut (Juglans regia L.). J. Agric. Food Chem. 2006, 54, 8033-8040. [CrossRef]

53. Chiș, M.S.; Păucean, A.; Stan, L.; Mureșan, V.; Vlaic, R.A.; Man, S.; Biriș-Dorhoi, E.S.; Muste, S. Lactobacillus plantarum ATCC 8014 in quinoa sourdough adaptability and antioxidant potential. Rom. Biotechnol. Lett. 2018, 23, 13581-13591.

54. Paucean, A.; Man, S.M.; Chis, M.S.; Muresan, V.; Pop, C.R.; Socaci, S.A.; Muresan, C.C.; Muste, S. Use of Pseudocereals Preferment Made with Aromatic Yeast Strains for Enhancing Wheat Bread Quality. Foods 2019, 8, 443. [CrossRef]

55. Pyo, Y.H.; Lee, T.C.; Logendra, L.; Rosen, R.T. Antioxidant activity and phenolic compounds of swiss chard (Beta vulgaris subspecies cycla) extracts. Food Chem. 2004, 85, 19-26. [CrossRef]

56. Duca, A.; Alexa, E.; Dehelean, C.A.; Șoica, C.; Danciu, C.; Popescu, I.; Cocan, I.; Lalescu, D.; Muntean, D.M. Assessment of lipid profile of eight propolis samples from western Romania. Farmacia 2019, 1, 126-132. [CrossRef]

57. The Pherobase Data base of Pheromones and Semio Chemicals. Available online: https://www.pherobase.com/ (accessed on 10 December 2019). 
58. Flavornet and human odor space. Available online: http://www.flavornet.org (accessed on 10 December 2019).

59. Dong, L.; Piao, Y.; Zhang, X.; Zhao, C.; Hou, Y.; Shi, Z. Analysis of volatile compounds from a malting process using headspace solid-phase micro-extraction and GC-MS. Food Res. Int. 2013, 51, 783-789. [CrossRef]

Sample Availability: Samples of the compounds are not available from the authors.

(C) 2020 by the authors. Licensee MDPI, Basel, Switzerland. This article is an open access article distributed under the terms and conditions of the Creative Commons Attribution (CC BY) license (http://creativecommons.org/licenses/by/4.0/). 